
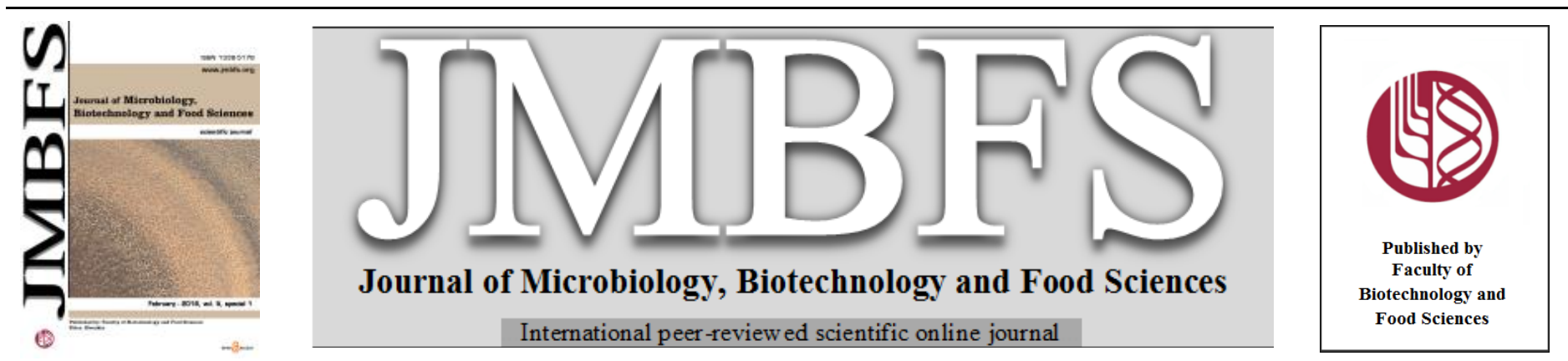

\title{
THE MODES OF VITAMIN E ADMINISTRATION AND ITS ROLE ON MEAT QUALITY: A MINI-REVIEW
}

\author{
Giuseppe Maiorano* and Siria Tavaniello
}

$\operatorname{Address(es):~}$

Department of Agricultural, Environmental and Food Sciences, University of Molise, Via F. De Sanctis, snc, 86100 Campobasso, Italy.

*Corresponding author: maior@unimol.it

doi: 10.15414/jmbfs.2016.5.special1.27-30

\section{ARTICLE INFO}

Received 25. 12. 2015

Revised 9. 1. 2016

Accepted 20.1.2016

Published 8. 2. 2016

Review

OPEN $\partial_{\text {ACCESS }}$

\begin{abstract}
Vitamin $\mathrm{E}$ is a well-established micro-nutrient for all animal species. Vitamin E-based additives are globally used in animal nutrition to prevent vitamin E deficiency and sustain animal health and production. Vitamin E as a lipid-soluble, chain-breaking antioxidant, protects cellular membranes from lipid peroxidation preserving the structural integrity of tissues. Vitamin $\mathrm{E}$ has been proposed as an effective method to reduce the oxidative processes in meat. Meat oxidation is the principal reason of the quality deterioration. The primary source of vitamin $\mathrm{E}$ is the natural tocopherols found in green plant materials and seeds. Among the synthetic forms of vitamin E, the acetate ester of all-rac $\alpha$-tocopherol (all-rac $\alpha$-tocopheryl acetate) is the most common form of vitamin E supplementations, due to its cost and stability in animal feeds. The route of administration (in feed or intramuscularly injected) plays a key role in enhancing the positive effect of vitamin E treatment. Several researches have proposed the intramuscular injection of vitamin E (dl- $\alpha$-tocopheryl acetate) as a strategy to: i) reduce vitamin E activity losses in feedstuffs; ii) ensure a more standardized administration in animals; iii) study its effect on growth performance, meat quality characteristics, oxidative stability and shelf life of meat products in different livestock animals. New perspective for the vitamin $\mathrm{E}$ supplementation in animal production regard the use of vitamin $\mathrm{E}$ as a feasible way to reduce the formation of carcinogenic substances in cooked meat with a consequent beneficial effect on human health.
\end{abstract}

\section{VITAMIN E: SOURCES AND MAIN FUNCTIONS}

Over the past decades, several studies have investigated the importance of an adequate vitamin $\mathrm{E}$ status to sustain both animal health and production. This vitamin was recognized as a necessary dietary supplement for growth, reproduction, immune function, disease prevention and tissue integrity (McDowell et al., 1996). Vitamin E is the generic term used for all tocol and tocotrienols derivatives that exhibit the activity of $\alpha$-tocopherol. The tocopherols are exclusively synthesized in photosynthetic organisms including higher plants. Significant amounts are found in all green tissues but predominantly occur in seeds. Vitamin E is abundant in whole cereal grains, particularly in germ, and in byproducts containing the germ; in fact, wheat germ oil was long used as a vitamin E supplement. The $\alpha$-tocopherol is especially high in wheat germ oil, safflower oil and sunflower oil. Corn and soybean oils contain predominantly $\gamma$ tocopherol, as well as some tocotrienols. Cottonseed oil contains both $\alpha$ - and $\gamma$ tocopherols in equal proportions (Zingg, 2007).

Vitamin $\mathrm{E}$ is principally known as a natural antioxidant, it can prevent peroxidative degradation of fats in animal cells and the consequent formation of free radicals. By scavenging reactive oxygen species, molecules that are produced through normal metabolism, vitamin $\mathrm{E}$ protects cell membranes against oxidative damage (Hatfield $\boldsymbol{e t}$ al., 2000). It is well known that oxidation is one of the main causes of quality deterioration in meat products with the development of off flavour, discoloration, formation of toxic compounds, poor shelf life, nutrient and drip losses (Morrisey et al., 1994; Kasapidou et al., 2012). In recent years, many studies (e.g. Macit et al., 2003 a, b; Maiorano et al., 2007, 2015 a, b) were conducted on the effect of vitamin E, supplemented in diet or intramuscular injected, on growth performance, meat quality characteristics, oxidative stability and shelf life of meat products in different livestock animals.

Considering that vitamin E cannot be synthesized by animals, the route and form of vitamin E administration play a key role as they strongly influence the level of serum, plasma and muscle vitamin E concentrations. Methods of providing supplemental vitamin $\mathrm{E}$ are: as part of a concentrate or liquid supplement and as an injectable product.

For many years, the primary source of vitamin $\mathrm{E}$ was the natural tocopherols found in green plant materials and seeds. In fact, several studies have shown that meat produced by cows fed at pasture contains higher levels of $\alpha$-tocopherol than cattle-fed high concentrate diets (Maiorano et al., 2005; De la Fuente et al., 2009; Luciano et al., 2011). In addition, compared with concentrate-based diets, pasture-based feeding systems generally produce greater concentrations of polyunsaturated fatty acids (PUFA) in muscle, but they also provide greater amounts of natural antioxidants (Wood et al., 2003). Comparisons of the effect of concentrate- or herbage-based diets on meat shelf life have frequently shown that feeding systems based on green forages confer on meat a superior resistance to oxidative deterioration due to the greater concentrations of antioxidant molecules in green herbage (Wood and Enser, 1997). D'Alessandro et al. (2012) found that the $\alpha$-tocopherol content of semimembranosus muscle of lambs suckled by pasture-fed mothers was found to be twice as higher as that of the lambs suckled by stall-fed mothers. Even if the content of vitamin $E$ in the sheep milk is very low $(6.54 \pm 0.25 \mu \mathrm{mol} / \mathrm{l})$ with a very high variability (Jelínek $\boldsymbol{e t}$ al.,1996), maternal milk might be considered an influential factor on the muscle concentration of vitamin $\mathrm{E}$ in lambs, since the pasture represents a relevant source of vitamin E for ruminants (Morrissey et al., 1998). However, it must be taken into account that vitamin $\mathrm{E}$ content and in general the nutritive value of range forage is influenced in a major way by: stage of maturity, edaphic influences, plant species, climate, animal class, and range condition (Oelberg, 1956; Duckett et al., 2013). As already mentioned, tocopherol is abundant in fresh pastures and forage, whereas stability of all naturally occurring tocopherols is poor and substantial losses of vitamin E activity occur in feedstuffs when processed and stored, as well as in manufacturing and storage of finished feeds (McDowell et al., 1996). Vitamin E sources in these ingredients are unstable under conditions that promote oxidation of feedstuffs such as heat, oxygen, moisture, oxidizing fats and trace minerals. 


\section{INTRAMUSCULAR INJECTIONS OF VITAMIN E: GROWTH PERFORMANCE AND MEAT QUALITY}

\section{Animals' growth}

In the recent years, several studies (reviewed in Maiorano et al., 2015a) have proposed the intramuscular injection of vitamin $\mathrm{E}$ (dl- $\alpha$-tocopheryl acetate) as a strategy to reduce the losses of vitamin $\mathrm{E}$ activity in feedstuffs and to ensure a more standardized administration in animals. Vitamin E administration, in diet or by injections, significantly increases the muscle $\alpha$-tocopherol contents (Salvatori et al., 2004; Kasapidou et al., 2012), as also confirmed by our recent study (Maiorano et al., 2015b). This latter study showed as well a significant difference in the $\alpha$-tocopherol concentrations between longissimus and vastus lateralis muscles of treated lambs (Figure 1). This variation between muscles is probably due to factors, such as functional and metabolic differences of muscle fibers and different fiber fat contents. However, Barja et al. (1996) found that the increase in the muscle $\alpha$-tocopherol concentration did not occur in a dosedependent manner. Usually, with the increasing of the administration quantity, there is an increasing in muscle concentration up to reach an optimal dose, to above which the effect of vitamin $\mathrm{E}$ in muscle starts to decrease. In addition, tissue accumulation of $\alpha$-tocopherol in animals treated or supplemented with vitamin E generally depends by numerous factors such as genotype of animal, dose, feeding time and type of muscle (Salvatori et al., 2004; Álvarez et al., 2008; Ripoll et al., 2013).

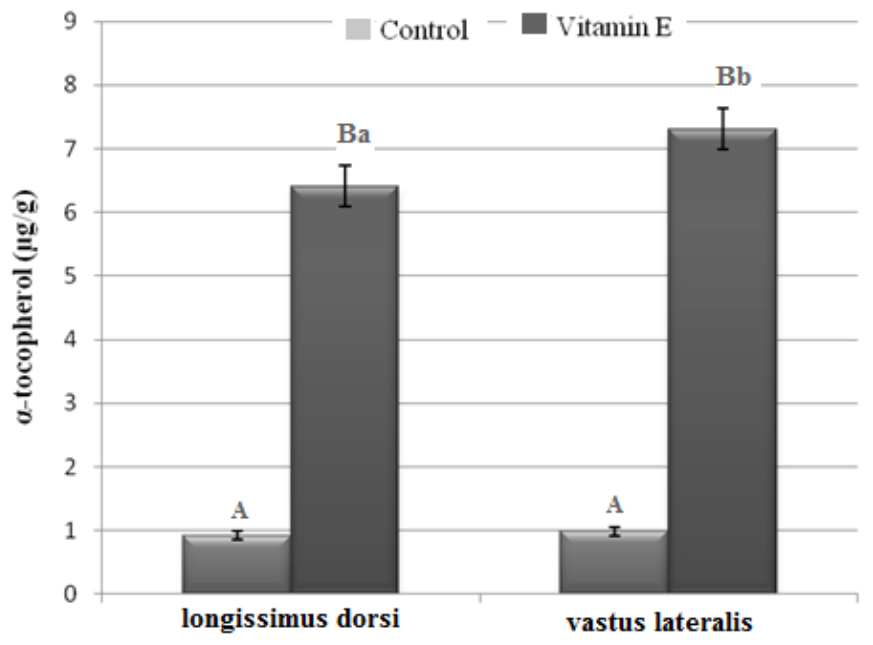

Figure 1 Content of $\alpha$-tocopherol $(\mu \mathrm{g} / \mathrm{g})$ in longissimus dorsi $(\mathrm{n}=12)$ and vastus lateralis $(\mathrm{n}=12)$ muscles between treatments and within treatment (mean $\pm \mathrm{SE}) .{ }^{\mathrm{A}}$, ${ }^{\mathrm{B}} P<0.01$, between treatments; ${ }^{\mathrm{a}, \mathrm{b}} P<0.05$, within treatment.

To deepen the knowledge on this topic we will focus on the vitamin E treatment of lambs, which is one of our main research lines. In a recent research, we studied the effects of intramuscular injection of vitamin $\mathrm{E}$ on performance, carcass traits, physicochemical and nutritional properties of meat, lipid oxidation, and consumer acceptability in Laticauda lambs, an autochthonous Italian sheep breed (Maiorano et al., 2015b). We found that vitamin E treatment did not influence growth but reduced hot dressing percentage. Contradictory data regarding the effect of vitamin $E$ on growth traits exist (Maiorano et al., 1999; 2007). Some works have demonstrated a beneficial effect of vitamin E treatment on growth traits in lambs (900 IU DL- $\alpha$-tocopheryl acetate, Gentry et al., 1992; 15 mg vitamin E per lamb per day, Macit et al., 2003a). Conversely, other authors (1500 IU $\alpha$-tocopherol, Birch et al., 1994; 1200 IU DL- $\alpha$-tocopheryl, Maiorano et al., 2007) observed a lower carcass weight and a negative effect on carcass wholesale cut weights in lambs injected with vitamin E. In addition, in our recent study (Maiorano et al., 2015a) we found that vitamin E did not influence growth, carcass weight, dressing percentage, carcass shrink losses and area of longissimus muscle but had a negative effect on pelvic limb percentage. It has been also reported that vitamin E-treated lambs had lower leg and shoulder weights (Birch et al., 1994) compared with control lambs. Hatfield et al. (2000) suggested that this might be due to vitamin E stimulation of the immune system that, in turn, caused a partitioning of energy away from growth and promoted muscle catabolism.

\section{Meat quality}

In our recent study (Maiorano et al., 2015b) we found that vitamin E treated lambs provided a more intensive colour meat. In fact, vitamin E supplementation delays the discoloration of meat by effectively controlling lipid oxidation and the accumulation of met-myoglobin in meat (Liu et al., 1995). This therefore confirms the importance of vitamin $\mathrm{E}$ in preserving meat redness that is one of the most important commercial characteristics of meat, because it is the colour that consumers tend to associate with freshness (Carpenter et al., 2001). Furthermore, the thiobarbituric acid reactive substances (TBARS) values, found in our research, clearly indicated that injected lambs were best protected from lipid oxidation, in accordance with previous studies on injected lambs (Salvatori et al., 2004), in supplemented lambs (Kasapidou et al., 2012) and in pork (Rossi et al., 2013). This is mainly related to the higher $\alpha$-tocopherol content in muscles of treated lambs, as confirmed by the negative correlation $(r=-0.46)$ between TBARS and muscle $\alpha$-tocopherol level. Regarding muscle cholesterol content we didn't find any significant effect of vitamin E treatment on it; however, it should be mentioned that vitamin $\mathrm{E}$ is associated with reduced production of cholesterol oxidation products which have toxic effects on human health (Buckley et al., 1995). On the contrary, a marked effect of vitamin $E$ treatment was found on muscle fatty acid composition. The treatment increased the total PUFA, the PUFA to saturated fatty acids (SFA) ratio and lowered the n-6 to n-3 ratio and the thrombogenic index. Barja et al. (1996) attributed the increase of PUFA levels in the liver of guinea pigs treated with DL $\alpha$-tocopherol acetate to a protective effect of vitamin E against PUFA peroxidation. On the other hand, as stated before, the presence of vitamin E within muscle cell membranes reduced lipid oxidation, improving the quality characteristics of meat (e.g. color, flavor, texture and nutritional value) extending its shelf-life, and also preventing the accumulation of toxic compounds, which may be detrimental to the health of consumers (Falowo et al., 2014). In light of this, we observed that meat from vitamin $E$ treated lambs received higher hedonic scores for tenderness and juiciness than the respective control. D'Alessandro et al. (2012) demonstrated that maternal feeding system (stall vs. pasture) affects consumer acceptability of lamb meat. The authors suggested that this effect could be due to higher $\alpha$-tocopherol content in the meat of pasture feeding lambs.

\section{Intramuscular collagen properties}

Tenderness can be explained by different characteristics (e.g. muscle fiber characteristics, intramuscular fat, collagen amount and the stability of its fibers). However, Sañudo et al. (2000) found no significant differences in tenderness despite differences in fatness. The higher score in tenderness of meat from treated lambs could be due to higher heat soluble connective tissue with cooked meat, favoured by the action of DL- $\alpha$-tocopheryl acetate that slows collagen maturation and reduce tenderness muscle index ( $\mu \mathrm{g}$ of Hydroxylysylpyridinoline crosslinks/mg of intramuscular collagen, Maiorano et al., 2001, 2007). In our recent study (Maiorano et al., 2015a) conducted on Ile de France suckling male lambs, we found that the DL- $\alpha$-tocopheryl acetate treatment reduced collagen maturity (HLP/collagen) and increased decorin in the longissimus muscle of growing lambs, while it did not affect intramuscular collagen (IMC) content Maiorano et al. $(\mathbf{1 9 9 9 , 2 0 0 7 )}$ focused on the effect of vitamin E on collagen and demonstrated that intramuscular injections of DL- $\alpha$-tocopheryl acetate (total dose of 1000 and $1200 \mathrm{IU} / \mathrm{animal}$ ) given to lambs (slaughtered at 40 days and 70 days old) may increase collagen solubility and reduce the IMC maturity. ArchileContreras et al. (2011) reported that vitamin E influences collagen metabolism in animals grown for meat. In particular, they observed that the addition of vitamin E ( $\alpha$-tocopherol acetate) to fibroblast cells, isolated from bovine semitendinosus and longissimus dorsi muscles, increased significantly total soluble collagen synthesis; while the collagen concentration for neither semitendinosus nor longissimus dorsi muscle cells responded to vitamin $\mathrm{E}$ in a dose-dependent manner. The authors suggested that the results may have implications in vivo on animal production, as a high rate of collagen turnover may lead to increased collagen solubility in muscles, which can affect meat tenderness. Collagen, the major component of the intramuscular connective tissue, it is believed to contribute to the initial toughness of meat as well as the sensation of chewiness (Duizer et al., 1996). An increase in collagen maturation leads to an increased IMC thermal stability, which has been related to undesirable changes in eating quality of meat (McCormick, 1999). It has been reported that vitamin $E$ increases the tenderness of pork (Dirinck $\boldsymbol{e t}$ al., 1996) and beef 
(Carnagey et al., 2008), but Macit et al. (2003b) found that vitamin E supplementation did not alter shear value of meat.

\section{VITAMIN E AND ANIMAL HEALTH}

Health is another important aspect of vitamin E supplementation that has to be considered. Vitamin E supplementation program utilizing both parenteral and oral administration is often suggested for livestock animals. Injectable vitamin $\mathrm{E}$ (with or without selenium) is available for calves and lambs at birth and 2-4 weeks after birth. Cows and ewes should receive the product 2 weeks prior to parturition. The product is also indicated for early arrival feedlot cattle and lambs as well as those animals which are not consuming adequate vitamin $\mathrm{E}$ supplemented diets or which are showing signs of a vitamin E deficiency. For continued protection of all cattle and sheep from a possible vitamin E deficiency, adequate supplemental vitamin $\mathrm{E}$ in the feed is essential (McDowell et al., 1996) The most common condition associated with vitamin $\mathrm{E}$ (and/or selenium) deficiency in lambs, but also in calves and kids, is the white muscle disease. It has also been reported that the deficiency of vitamin E, along with associated nutrients such as selenium and sulfur-containing amino acids, can result in pathological conditions such as encephalomalacia, exudative diathesis, nutritiona muscular dystrophy (NMD) in chicks, ducks, and turkeys (Klasing, 2008). In light of this, livestock producers will need to employ different strategies to compensate the potential deficiency in the status of vitamin E, considering also the increased nutritional requirements of the fast-growing and high-producing animals. Recent studies have found an emerging meat defect known as "white striping" (WS), which is a new condition affecting poultry breast fillets, principally related to selection for increasing growth rate and breast yield of modern hybrid birds (Petracci et al., 2013). The etiological causes of WS are still poorly understood. Considering the observed similarity in the appearance between NMD and WS, Kuttappan et al. (2012) carried out a study to evaluate the effect of the increments of dietary vitamin E (DL- $\alpha$-tocopherol acetate: 15 , $50,100,200$, and $400 \mathrm{IU} / \mathrm{kg}$ of fed) on the occurrence of various degrees of WS on broiler breast fillets; however, they did not find any significant association in the occurrence of WS in broiler breast fillets. This implies that, in contrast to NMD, an increased level of dietary vitamin E cannot prevent the occurrence of WS. However, it must be taken into account that the requirement of vitamin $\mathrm{E}$ may be influenced by various factors affecting the variability of vitamin $\mathrm{E}$ in feedstuffs and the physiological status of the birds. Some of these factors are the amount, type, and degree of oxidation of fat present in the diet, presence of other dietary antioxidants such as selenium, iron, copper, sulfur-containing amino acids, and harvesting, drying, or storage conditions of feeds that results in destruction of vitamin E (Hidiroglou et al., 1992). In light of this and considering that the intramuscular route could be considered a successful strategy to reduce the losses of vitamin E activity in feedstuffs, we started a new research work, currently in progress, to evaluate the effect of vitamin injection on growth, meat quality and occurrence of WS in fast-growing compared with slow-growing broilers reared indoor or with outdoor access.

\section{NEW PERSPECTIVE FOR THE VITAMIN E SUPPLEMENTATION IN ANIMAL PRODUCTION}

In the recent years, several studies (e.g. Pearson et al., 1992; Balogh $\boldsymbol{e t}$ al. 1999) have demonstrated the ability of Vitamin E, as a potent antioxidant compound, to inhibit the formation of mutagenic/carcinogenic heterocyclic amines (HAs) and polycyclic aromatic hydrocarbons (PAHs). Vitamin E is able to inhibit HA-induced mutagenesis or carcinogenesis as a result of different actions interfering at various steps of the HAs formation and of HA-toxic activity. In fact, antioxidants can act as inhibitors along the different pathways of the reaction, preventing the mutagens formation, through radical quenchers and free radical scavengers activity; as blocking agents, preventing the biotransformation of premutagens into reactive metabolites by inhibiting metabolic activation, by stimulating detoxification enzymes, or by scavenging reactive molecules; as suppressing agents modulating intracellular processes, which are involved in DNA repair mechanisms, tumour promotion and tumour progression (Vitaglione and Fogliano, 2004). Our preliminary results, regarding the utilization of vitamin E solution for marinating meat before grill cooking at high temperature, showed the inhibition effect of vitamin $\mathrm{E}$ against the formation of carginogenic compounds (Di Memmo et al., 2012). However, more studies are needed to further address the inhibition of HAs and PAHs formation in cooked meats by vitamin E (intramuscular injected or from pasture). This clearly involves more detailed studies on the mechanism of HAs and PAHs formation in meat, considering also that the presence of these undesirable substances depends on many factors such as meat type, cooking method, time and temperature, the presence of relative amounts of precursors, enhancers and inhibitors, lipids, antioxidants and the water content. In conclusion, vitamin $\mathrm{E}$ as other natural antioxidant substances could be a feasible way to reduce the HAs and PAHs dietary intake with a possible reduction of the risk associated to HAs/PAHsinduced mutagenicity/carcinogenicity with a consequent beneficial effect on human health.

\section{REFERENCES}

ÁlVAREZ, I., DE LA FUENTE, J.D., DÍAZ, M. T., LAUZURICA, S., PÉREZ C., CAÑEQUE, V. 2008. Estimation of $\alpha$-tocopherol concentration necessary to optimise lamb meat quality stability during frozen storage in high-oxygen modified using broken line regression analysis. Animal, 2, 1405-1411. http://dx.doi.org/10.1017/S1751731108002590

ARCHILE-CONTRERAS, A.C., CHA, M.C., MANDELL, I.B., MILLER, S.P., PURSLOW, P.P., 2011. Vitamins E and C may increase collagen turnover by intramuscular fibroblasts. Potential for improved meat quality. Journal of Agricultural and Food Chemistry, 59, 608-614. http://dx.doi.org/10.1021/jf103696t

BALOGH, Z., GRAY, J.I., GOMAA, E.A., BOOREN, A.M., 2000. Formation and inhibition of heterocyclic aromatic amines in fried ground beef patties. Food and Chemical Toxicology, 38, 395-401. http://dx.doi.org/10.1016/S02786915(00)00010-7

BARJA, G., CADENAS, S., ROJAS, C., PÉREZ-CAMPO, R., LÓPEZTORRES, M., PRAT, J., PAMPLONA R., 1996. Effect of dietary vitamin E levels on fatty acid profiles and non-enzymatic lipid peroxidation in the guinea pig liver. Lipids, 31, 963-970. http://dx.doi.org/10.1007/BF02522690

BIRCH, K.S., THOMAS, J.D., ROSS, T.T., 1994. Growth and carcass characteristics of newly received feeder lambs treated with probiotics and vitamin E. Sheep Goat Research Journal, 10, 201-206

BUCKLEY, D.J., MORRISSEY, P.A., GRAY J.I., 1995. Influence of dietary vitamin $\mathrm{E}$ on the oxidative stability and quality of pig meat. Journal of Animal Science, 73, 3122-3130. http://dx.doi.org/1995.73103122x

CARNAGEY, K.M., HUFF-LONERGAN, E.J., TRENKLE, A., WERTZ-LUTZ, A.E., HORST, R.L. BEITZ, D.C., 2008. Use of 25-hydroxyvitamin D3 and vitamin $\mathrm{E}$ to improve tenderness of beef from the longissimus dorsi of heifers. Journal of Animal Science, 86, 1649-1657. http://dx.doi.org/10.2527/jas.2007$\underline{0502}$

CARPENTER, C.E., CORNFORTH, D.P., WHITTIER, D., 2001. Consumer preferences for beef color and packaging did not affect eating satisfaction. Meat Science, 57, 359-363. http://dx.doi.org/10.1016/S0309-1740(00)00111-X

D'ALESSANDRO, A.G., MAIORANO, G., KOWALISZYN, B., LOIUDICE, P., MARTEMUCCI, G., 2012. How the nutritional value and consumer acceptability of suckling lamb meat is affected by maternal feeding system. Small Ruminant Research, 106, 83-91. http://dx.doi.org/10.1016/j.smallrumres.2012.02.001

DE LA FUENTE, J., DIAZ, M.T., ALVAREZ, I., OLIVER, M.A., FONTI FURNOLS, M., SAÑUDO, C., CAMPO, M.M., MONTASSI, F., NUTI, G.R., CANEQUE, V., 2009. Fatty acid and vitamin E composition of intramuscular fat in cattle reared in different production systems. Meat Science, 82, 331-337. http://dx.doi.org/10.1016/i.meatsci.2009.02.002

DI MEMMO, D., GAMBACORTA, M., MAIORANO, G., 2012. Preliminary results on the effects of antioxidants and of cooking method on the formation of HCAs and PAHs in cooked meat. International Ph.D. Workshop on "Welfare, Biotechnology and Quality of Animal Production", Zielonka (Poland), 5-8 September 2012.

DIRINCK, P., DE WINNE, A., CASTEELS, M., FRIGG, M., 1996. Studies on vitamin $\mathrm{E}$ and meat quality. 1. Effect of feeding high vitamin $\mathrm{E}$ levels on timerelated pork quality. Journal of Agricultural and Food Chemistry, 44, 65-68. http://dx.doi.org/10.1021/jf940607x

DUCKETT, S.K., NEEL, J.P.S., LEWIS, R.M., FONTENOT, J.P., CLAPHAM, W.M., 2013. Effects of forage species or concentrate finishing on animal performance, carcass and meat quality. Journal of Animal Science, 91, 1454 1467. http://dx.doi.org/10.2527/jas.2012-5914

DUIZER, L.M., GULLETT, E.A., FINDLAY, C.J., 1996. The relationship between sensory time-intensity, physiological electromyography and 
instrumental texture profile analysis measurements of beef tenderness. Meat Science, 42, 215-224. http://dx.doi.org/10.1016/0309-1740(95)00022-4

FALOWO, A.B., FAYEMI P.O., MUCHENJE V., 2014. Natural antioxidants against lipid-protein oxidative deterioration in meat and meat products: A review. Food Research International, 64, 171-181. http://dx.doi.org/10.1016/j.foodres.2014.06.022

GENTRY, P.C., ROSS, T.T., OETTING, B.C., BIRCH, K.D., 1992. Effects of supplemental dl-a-tocopherol on preweaning lamb performance, serum and colostrum tocopherol levels and immunoglobulin G titers. Sheep Goat Research Journal, 8, 95-100.

HATFIELD, P.G., DANIELS, J.T., KOTT, R.W., BURGESS, D.E., EVANS, T.J., 2000. Role of supplemental vitamin $\mathrm{E}$ in lamb survival and production: A review. Journal of Animal Science, 77, 1-9. http://dx.doi.org/10.2134/jas2000.77E-Suppl1a

HIDIROGLOU, N., CAVE, N., ATWALL, A.S., FARNWORTH, E.R., MCDOWELL, L.R., 1992. Comparative vitamin E requirements and metabolism in livestock. Annals of Veterinary Research, 23, 337-359. https://hal.archivesouvertes.fr/hal-00902095

JELÍNEK, P., GAJDUSĚK, S., ILLEK, J., 1996. Relationship between selected indicators of milk and blood in sheep. Small Ruminant Research, 20, 53-57. http://dx.doi.org/10.1016/0921-4488(95)00771-7

KASAPIDOU, E., WOOD, J.D., RICHARDSON, R.I., SINCLAIR, L.A., WILKINSON, R.G., ENSER, M., 2012. Effect of vitamin E supplementation and diet on fatty acid composition and on meat colour and lipid oxidation of lamb leg steaks displayed in modified atmosphere packs. Meat Science, 90, 908-916. http://dx.doi.org/10.1016/j.meatsci.2011.11.031

KLASING, K.C., 2008. Nutritional diseases. Pages 1027-1054 in Diseases of Poultry. 12th ed. Saif, Y. M., Fadley, A. M., Glisson, J. R., McDougald, L. R., Nolan, L. K., Swayne, D. E. Ames, IA: Blackwell Publishing Professional.

KUTTAPPAN, V.A., GOODGAME, S.D., BRADLEY, C.D., MAUROMOUSTAKOS, A., HARGIS, B.M., WALDROUP, P.W., OWENS, C.M., 2012. Effect of different levels of dietary vitamin E (dl- $\alpha$-tocopherol acetate) on the occurrence of various degrees of white striping on broiler breast fillets. Poultry Science, 91, 3230-3235. http://dx.doi.org/10.3382/ps.2012-02397 LIU, Q., LANARI, M.C., SCHAEFER, D.M., 1995. A review of dietary vitamin E supplementation for improvement of beef quality. Journal of Animal Science, 73, 3131-3140. http://dx.doi.org/1995.73103131x

LUCIANO, G., MOLONEY, A.P., PRIOLO, A., ROHRLE, F.T., VASTA, V., BIONDI, L., LOPEZ-ANDRES, P., GRASSO, S., MONAHAN, F.J., 2011. Vitamin $\mathrm{E}$ and polyunsaturated fatty acids in bovine muscle and the oxidative stability of beef from cattle receiving grass or concentrate-based rations. Journal of Animal Science, 89, 3759-3768. http://dx.doi.org/10.2527/jas.2010-3795

MACIT, M., AKSAKAL, V., AMSEN, E., AKSU, M.L. 2003a. Effects of vitamin $\mathrm{E}$ supplementation on performance and meat quality traits of Morkaraman male lambs. Meat Science, 63, 51-55. http://dx.doi.org/10.1016/S0309-1740(02)00052-9

MACIT, M., AKSAKAL, V., AMSEN, E., ESENBUGA, N., AKSU, M.I., 2003b. Effects of vitamin $E$ supplementation on fattening performance noncarcass components and retail cuts percentages and meat quality traits of Awassi lambs. Meat Science, 64, 1-6. http://dx.doi.org/10.1016/S0309-1740(02)00115-8 MAIORANO, G., ANGWECH, H., DI MEMMO, D., WILKANOWSKA, A., MUCCI, R., ABIUSO, C., TAVANIELLO, S., 2015b. Effects of intramuscular Vitamin E multiple injection on quality, oxidative stability and consumer acceptability of Laticauda lamb meat. Submitted to Small Ruminant Research.

MAIORANO, G., CAVONE, C., MCCORMICK, R.J., CIARLARIELLO, A., GAMBACORTA, M., MANCHISI, A., 2007. The effect of dietary energy and vitamin $\mathrm{E}$ administration on performance and intramuscular collagen properties $\begin{array}{lllll}\text { of lambs. } & \text { Meat } & \text { Science } & \text { 182 }\end{array}$ http://dx.doi.org/10.1016/j.meatsci.2006.11.001

MAIORANO, G., FILETTI, F., SAlVATORI, G., GAMBACORTA, M., BELLETTI, A., ORIANI, G., 2001. Growth, slaughter and intra-muscular collagen characteristics in Garganica kids. Small Ruminant Research, 39, 289294. http://dx.doi.org/ 10.1016/S0921-4488(00)00207-8

MAIORANO, G., MANCHISI, A., SALVATORI, G., FILETTI, F., ORIANI, G., 1999. Influence of multiple injections of vitamin $E$ on intramuscular collagen and bone characteristics in suckling lambs. Journal of Animal Science, 77, 24522457. http://dx.doi.org/1999.7792452x

MAIORANO, G., PRISCIANTELLI, A., CAVONE, C., GAMBACORTA, M., MANCHISI, A., 2005. Influence of vitamin E treatment starting time on lamb meat quality. Italian Journal of Animal Science, 4, 363-365. http://dx.doi.org/10.4081/ijas.2005.2s.363

MAIORANO, G., WILKANOWSKA, A., TAVANIELLO, S., DI MEMMO, D., DE MARZO, D., GAMBACORTA, M., 2015a. Effect of intramuscular injections of DL- $\alpha$-tocopheryl acetate on growth performance and extracellular matrix of $\begin{array}{llll}\text { growing lambs. } & \text { Animal, } & \text { 9, }\end{array}$ http://dx.doi.org/10.1017/S175173111500155X

MCCORMICK, R.J., 1999. Extracellular modifications to muscle collagen implications for meat quality. Poultry Science, 78, 785-791. http://dx.doi.org/10.1093/ps/78.5.785

MCDOWELL, L.R., WILLIAMS, S.N., HIDIROGLOU, N., NJERU, C.A., HILL, G.M., OCHOA, L., WILKINSON, N.S., 1996. Vitamin E supplementation for the ruminant. Animal Feed Science Technology, 60, 273-296. http://dx.doi.org/10.1016/0377-8401(96)00982-0

MORRISEY, P.A., BUCKLEY, D.J., SHEEHY, P.J.A., MONAHAN, F.J., 1994 Vitamin E and meat quality. Proceedings of the Nutrition Society 53, 289-295. http://dx.doi.org/10.1079/PNS19940034

OELBERG, K., 1956. Factors affecting the nutritive value of range forage. Journal of Range Management, 9, 220-225. http://dx.doi.org/

PEARSON, A.M., CHEN, C., GRAY, J.I., AUST, S.D. 1992. Mechanism(s) involved in meat mutagen formation and inhibition. Free Radical Biology and Medicine, 13, 161-167. http://dx.doi.org/10.1016/0891-5849(92)90078-U

PETRACCI, M., MUDALAL, S., BONFIGLIO, A., CAVANI, C., 2013. Occurrence of white striping under commercial conditions and its impact on breast meat quality in broiler chickens. Poultry Science, 92, 1670-1675. http://dx.doi.org/10.3382/ps.2012-03001

RIPOLL, G., GONZÁLES-CALVO, L., MOLINO, F., CALVO, J.H., JOY, M., 2013. Effects of finishing period length with vitamin $\mathrm{E}$ supplementation and alfalfa grazing on carcass colour and the evolution of meat color and the lipid oxidation of light lambs. Meat Science, 93, 906-913 http://dx.doi.org/10.1016/j.meatsci.2012.09.017

ROSSI, R., PASTORELl, G., CANNATA, S., TAVANIELlO, S. MAIORANO, G., CORINO, C., 2013. Effect of long term dietary supplementation with plant extract on carcass characteristics meat quality and oxidative stability in pork. Meat Science, 95, 542-548. http://dx.doi.org/10.1016/j.meatsci.2013.05.037

SAlVATORI, G., PANTAleO, L., DI CESARE, C., MAIORANO, G., FILETTI, F., ORIANI, G., 2004. Fatty acid composition and cholesterol content of muscle as related to genotype and vitamin E treatment in crossbred lambs. Meat Science, 67, 45-55. http://dx.doi.org/10.1016/j.meatsci.2003.09.004

SAÑUDO, C., ENSER, M.E., CAMPO, M.M., NUTE, G.R., MARIA, G.A., SIERRA, I., WOOD, J.D., 2000. Fatty acid composition and sensory characteristics of lamb carcasses from Britain and Spain. Meat Science, 54, 339346. http://dx.doi.org/10.1016/S0309-1740(99)00108-4

VITAGLIONE, P., FOGLIANO, V., 2014. Use of antioxidants to minimize the human health risk associated to mutagenic/carcinogenic heterocyclic amines in food. Journal of Chromatography B, 802, 189-199. http://dx.doi.org/10.1016/j.jchromb.2003.09.029

WOOD, J.D., ENSER, M. 1997. Factors influencing fatty acids in meat and the role of antioxidants in improving meat quality. British Journal of Nutrition, 78, S49-S60. http://dx.doi.org/10.1079/BJN19970134

WOOD, J.D., RICHARDSON, R.I., NUTE, G.R., FISHER, A.V., CAMPO, M.M., KASAPIDOU, E., SHEARD, P.R., ENSER, M. 2003. Effects of fatty acids on meat quality: A review. Meat Science, 66, 21-32. http://dx.doi.org/10.1016/S0309-1740(03)00022-6

ZINGG, J.M. 2007. Vitamin E: An overview of major research directions. Molecular Aspects of Medicine, 28, 400-422. http://dx.doi.org/10.1016/j.mam.2007.05.004 